\title{
Pengaruh Kecerdasan Intelektual, Kecerdasan Emosional, Kompetensi dan Lingkungan Kerja pada Kinerja Auditor
}

\author{
Ni Luh Yuni Pratiwi ${ }^{1}$ \\ Fakultas Ekonomi dan Bisnis \\ Universitas Udayana, Indonesia \\ Email: yunipratiwi762@gmail.com
}

\author{
I Ketut Suryanawa ${ }^{2}$ \\ Fakultas Ekonomi dan Bisnis \\ Universitas Udayana, Indonesia
}

\begin{abstract}
ABSTRAK
Tujuan penelitian ini adalah untuk memperoleh bukti empiris mengenai pengaruh kecerdasan intelektual, kecerdasan emosional, kompetensi dan lingkungan kerja pada kinerja auditor. Penelitian ini dilakukan di Kantor Akuntan Publik (KAP) di Bali. Populasi dalam penelitian ini adalah seluruh auditor yang bekerja pada KAP di Bali. Sampel penelitian ini berjumlah 55 responden, dilakukan dengan teknik sampling jenuh. Data yang digunakan yaitu data primer dengan metode pengumpulan data kuesioner. Teknik analisis data yang digunakan adalah analisis regresi linear berganda. Hasil penelitian ini menunjukkan, bahwa kecerdasan intelektual, kecerdasan emosional, kompetensi dan lingkungan kerja berpengaruh positif pada kinerja auditor. Hasil penelitian ini sebagai gambaran dan masukan bagi pimpinan Kantor Akuntan Publik dalam mengupayakan kinerja yang lebih baik, serta bagi auditor dapat digunakan sebagai bahan evaluasi untuk menjaga dan meningkatkan kinerjanya dalam melakukan audit. Hasil penelitian ini juga dapat menjadi pertimbangan bagi klien dalam memilih auditor yang profesional dan berpengalaman.
\end{abstract}

Kata Kunci: Kecerdasan Intelektual; Kecerdasan Emosional; Kompetensi; Lingkungan Kerja; Kinerja Auditor.

\section{Effects of Intellectual Intelligence, Emotional Intelligence, Competence and Work Environment on Auditor Performance}

\section{ABSTRACT}

The purpose of this study is to obtain empirical evidence about the influence of intellectual intelligence, emotional intelligence, competence and work environment on auditor performance. This research was conducted at the Public Accounting Firm (KAP) in Bali. The population in this study are all auditors who work at KAP in Bali. The sample of this study was 55 respondents, carried out with saturated sampling technique. The data used are primary data with data collection methods namely questionnaires. The data analysis technique used in this study is multiple linear regression analysis. The results of this study indicate that intellectual intelligence, emotional intelligence, competence and work environment have a positive effect on auditor performance. The results of this study as input for the leadership of the Public Accounting Firm in seeking betterperformance, and for the auditor can be used as evaluation material to maintain and improve performance in conducting audits.

Keywords: Intellectual Intelligence; Emotional Intelligence; Competence; Work environment; Auditor Performance.

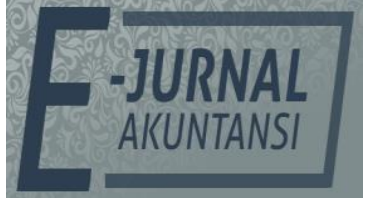

E-JA

e-Jurnal Akuntansi e-ISSN 2302-8556

Vol. 30 No. 7

Denpasar, Juli 2020

Hal.1738-1749

Artikel Masuk: 5 Maret 2020

Tanggal Diterima: 22 Juni 2020

The Article is Available in : https://ojs.unud.ac.id/index.php/Akuntansi/index 


\section{PENDAHULUAN}

Auditor yang cerdas secara intelektual belum tentu menghasilkan kinerja yang optimal dalam melakukan proses audit, karena auditor yang hanya memiliki kemampuan berpikir dan menalar saja, namun tidak memiliki kemampuan untuk mengelola emosi diri dan bertahan menghadapi frustasi, maka auditor tidak bisa menyesuaikan diri dalam menghadapi masalah, hal tersebut dapat mengakibatkanauditor merasa tertekan dan tidak fokus dalam melaksanakan tugasnya. Auditor yang cerdas secara emosional akan memberikan kinerja yang lebih baik dalam menghasilkan laporan audit. Kalbers \& Fogarthy (1995) menyatakan bahwa kinerja auditor merupakan evaluasi terhadap pekerjaan yang dilakukan oleh atasan, rekan kerja, diri sendiri, dan bawahan langsungnya. Kinerja sering digunakan untuk menyebut prestasi atau tingkat keberhasilan individu maupun kelompok individu (Husam et al., 2013). Kinerja auditor dapat dilihat dari kemampuannya dalam mengelola diri sendiri dan kemampuan membina hubungan dengan orang lain. Kemampuan tersebut disebut kecerdasan emosi, yang memberikan pengaruh terhadap diri seseorang. Penelitian yang dilakukan oleh Apriyanti (2014) dan Kristiyanti (2017) menemukan bahwa kecerdasan emosional berpengaruh positif pada kinerja auditor.

Kompetensi merupakan kemampuan yang dimiliki oleh seseorang, kemampuan tersebut berupa pengetahuan, keahlian dan sikap yang dimiliki setiap individu untuk melakukan tugas dan pekerjaannya. Menurut Yadnya \& Ariyanto (2017) seorang yang berkompeten adalah orang yang dengan keterampilannya mengerjakan pekerjaan dengan mudah, cepat dan sangat jarang membuat sebuah kesalahan. Auditor yang berpengalaman merupakan auditor yang ahli karena memiliki keunggulan dalam beberapa hal yaitu mendeteksi kesalahan, memahami kesalahan dengan akurat dan mengetahui penyebab kesalahan. Semakin berpengalaman dan profesional seorang auditor, maka keputusan yang diambil akan semakin mendekati "dapat dipertanggungjawabkan", dan auditor yang berkualitas tinggi diharapkan mampu memberikan tingkat kredibilitas tinggi bagi para pemakai laporan audit (Tubbs, 1992). Penelitian yang dilakukan oleh Ariani \& Badera (2015) serta Yadnya \& Ariyanto (2017) menemukan bahwa kompetensi berpengaruh positif pada kinerja auditor.

Faktor lain yang mempengaruhi kinerja seorang auditor adalah lingkungan kerja. Lingkungan kerja adalah tempat dimana auditor melakukan aktivitas setiap harinya. Darmayanti (2018) menyatakan lingkungan kerja yang kondusif memberikan rasa aman, nyaman dan memungkinkan pegawai (dalam hal ini auditor) untuk dapat bekerja dengan optimal. Begitu pula sebaliknya, jika lingkungan kerjanya menyebabkan rasa tertekan dan tidak nyaman, maka auditor tidak dapat bekerja dengan optimal sehingga mempengaruhi hasil kerjanya.

Kondisi lingkungan kerja auditor yang bertempat di Bali saat ini, hanya terdapat 13 Kantor Akuntan Publik (KAP), dimana jumlah tersebut masih tergolong sangat sedikit jika dibandingkan dengan jumlah perusahaan yang membutuhkan auditor untuk melakukan jasa audit yang terus bertambah seiring dengan berjalannya waktu. Minimnya jumlah auditor dan banyaknya jumlah 
perusahaan yang memerlukan jasa audit mengakibatkan auditor dituntut untuk bekerja lebih cepat, sehingga hal tersebut juga akan memengaruhi kinerjanya.

Kecerdasan intelektual adalah kemampuan untuk melakukan analisis verbal, logika, numberik. Kecerdasan ini meberikan kemampuan untuk menangkap, menyimpan, dan mengelola informasi menjadi fakta dan mampu berpikir secara rasional dalam melakukan pemeriksaan/audit (Ratnantari \& Putri, 2017). Menurut Wiguna \& Yadnyana (2019) merumuskan bahwa kecerdasan intelektual adalah kemampuan untuk memperoleh, mengingat, dan menggunakan pengetahuan. Robbins \& Judge (2008:57) mengatakan bahwa kecerdasan intelektual adalah kemampuan yang dibutuhkan untuk melakukan berbagai aktivitas mental berpikir, menalar dan memecahkan masalah. Tanpa memiliki kecerdasan intelektual seorang auditor tidak dapat memahami dan mengaplikasikan pengetahuan yang diperoleh baik dalam bidang akuntansi maupun auditing dalam melaksanakan tugasnya, jika auditor memiliki kecerdasan intelektual, maka auditor dapat melakukan pemeriksaan dengan baik dalam menentukan opini audit, sehingga kinerja yang akan dicapai juga semakin baik.

Penelitian yang dilakukan oleh Yuliana \& Latrini (2016) menunjukan bahwa kecerdasan intelektual berpengaruh positif terhadap kinerja auditor. Kecerdasan intelektual adalah kemampuan mental yang melibatkan proses berpikir secara rasional. Ratnantari \& Putri (2017) menyatakan tingginya kecerdasan intelektual yang dimiliki oleh seorang auditor akan membantu auditor dalam menyerap ilmu yang diberikan sehingga kemampuannya dalam menemukan dan memecahkan masalah yang berkaitan dengan pekerjaannya akan lebih baik.

$\mathrm{H}_{1}$ : Kecerdasan intelektual berpengaruh positif pada kinerja auditor.

Kecerdasan Emosional adalah kemampuan memberikan kepercayaan diri, mengelola emosi ketika menghadapi tekanan, memberi motivasi pada diri sendiri dan kemampuan untuk bekerjasama dan berinteraksi dengan orang lain (Ratnantari \& Putri, 2017). Kemampuan mengelola emosi dapat berupa kesanggupan menghadapi frustasi, stres dalam melakukan pemeriksaan sehingga tetap bisa berfikir secara jernih dan profesional walaupun dalam keadaan tertekandan tetap fokus dalam mendeteksi kesalahan yang dapat mempengaruhi opini audit. Kecerdasan emosional diharapkan dapat meningkatkan sikap positif terhadap pekerjaan, dan mendorong perilaku positif dan hasil yang lebih baik (Sony \& Mekoth, 2016)

Kecerdasan emosional merupakan salah satu hal penting di tempat kerja, yang meliputi penyesuaian dalam menghadapi masalah, manajemen diri, efektivitas antar pribadi, keterampilan diskusi dalam menghadapi berbagai pendapat dan ketidak sepakatan (Amilin, 2017). Auditor membutuhkan kecerdasan emosional yang tinggi karena dalam lingkungan kerjanya auditor akan berinteraksi dengan orang banyak baik di KAP maupun ditempat klien. Kecerdasan emosional yang tinggi berdampak pada kemampuan individu untuk menghadapi tantangan dan menjadikannya sebagai individu yang bertanggungjawab, produktif, dan optimis dalam menghadapi dan menyelesaikan masalah, dimana hal-hal ini diperlukan di lingkungan kerja (Hasanuddin \& Sjahruddin, 2017). Menurut Cook et al. (2011) kecerdasan 
emosional dapat menjadikan seseorang untuk mampu memotivasi diri, memiliki ketahanan dalam menghadapi kegagalan, mengendalikan emosi dan menunda kepuasan, serta mengatur keadaan jiwa. Jika seseorang dapat mengontrol emosinya dengan baik maka akan dapat menghasilkan kinerja yang baik pula. Hal ini sesuai dengan yang diungkapkan oleh Watkin (2000) bahwa kecerdasan emosional merupakan salah satu faktor yang paling penting yang akan menghasilkan kinerja yang lebih optimum.

Beberapa peneliti terdahulu percaya bahwa karyawan (dalam hal ini auditor) yang dapat mengontrol dan mengelola stres dengan baik ketika bekerja, maka kinerjanya akan semakin tinggi (Ciarrochi et al., 2002). Menurut Kristiyanti (2017) variabel kecerdasan emosional berpengaruh positif dan signifikan terhadap kinerja auditor. Hasil penelitian Apriyanti (2014) menyatakan variabel kecerdasan emosional berpengaruh signifikan secara parsial terhadap kinerja auditor. Berdasarkan uraian diatas, maka peneliti dengan ini mengajukan hipotesis sebagai berikut:

$\mathrm{H}_{2}$ : Kecerdasan emosional berpengaruh positif pada kinerja auditor.

Kompetensi merupakan kemampuan yang dimiliki oleh seseorang, kemampuan tersebut berupa pengetahuan, keahlian dan sikap yang dimiliki setiap individu untuk melakukan tugas dan pekerjaannya. Kompetensi yang baik akan menentukan output dari hasil pekerjaannya. Menurut Furiady dan Kurnia (2015) kompetensi auditor adalah kemampuan auditor untuk menerapkan pengetahuan dan pengalaman yang sudah dimiliki, sehingga auditor dapat menemukan kesalahan dengan cermat, hati-hati dan obyektif. Menurut $\mathrm{Wu}$ et.al (2017) ada tiga indikator pengukuran kompetensi yaitu pengetahuan, keterampilan dan sikap kerja yang sesuai dengan standar yang ditetapkan. Brown, et al (2007) auditor akan dapat menyelesaikan auditnya secara efektif jika didukung kemampuan, karena dengan kemampuan maka auditor dapat mendeteksi kesalahan yang akan berimbas pada kinerja yang membaik. Apabila auditor memiliki kompetensi yang baik, maka pemahaman yang dimiliki atas suatu laporan keuangan juga akan lebih baik sehingga auditor dengan cepat akan dapat menganalisis kesalahan yang terjadi. Dengan memiliki kompetensi atau keahlian dalam jasa profesionalnya, maka akan mempengaruhi laporan hasil pemeriksaan yang merupakan salah satu penilaian terhadap kinerja auditor.

Hasil penelitian Ariani dan Badera (2015) menunjukan bahwa kompetensi berpengaruh positif pada kinerja auditor. Yadnya dan Ariyanto (2017) menyatakan bahwa kompetensi berpengaruh positif pada kinerja auditor.Berdasarkan uraian diatas, maka peneliti dengan ini mengajukan hipotesis sebagai berikut:

$\mathrm{H}_{3}$ : Kompetensi berpengaruh positif pada kinerja auditor.

Lingkungan kerja adalah segala sesuatu yang ada di lingkungan pekerja yang dapat mempengaruhi dirinya dalam menjalankan tugas yang dibebankan. Lingkungan kerja yang menyenangkan dan terpenuhinya kebutuhan dalam bekerja akan memberikan rasa puas dan mendorong semangat kerja, karena berawal dari kenyamanan auditor dalam bekerja, hubungan yang baik dengan rekan kerja dan klien, serta tersedianya fasilitas kerja maka dapat meningkatkan semangat kerja sehingga kinerjanya optimal (Erawan, 2018). 
Menurut Pitaloka \& Sofia (2014) lingkungan kerja juga merupakan atribut dalam organisasi yang mempengaruhi seseorang dalam menyelesaikan pekerjaan mereka. Lingkungan kerja yang kondusif memberikan rasa aman dan memungkinkan para auditor untuk dapat bekerja secara optimal, serta dapat mempengaruhi dirinya dalam menjalankan tugas-tugas yang dibebankan (Dharmanegara et.al, 2016). Menurut Wardhani \& Lesmana (2014) salah satu faktor yang dapat mempengaruhi produktivitas karyawan (dalam hal ini seorang akuntan publik) adalah lingkungan kerja. Lingkungan kerja auditor dapat dibagi menjadi dua yaitu lingkungan kerja di tempat klien dan di Kantor Akuntan Publik (KAP). Pada saat auditor melaksanakan kerja lapangan atau bekerja di tempat klien, maka auditor akan berinteraksi dengan banyak orang yang memiliki sifat dan perilaku berbeda hal tersebut tentu dapat memengaruhi emosional seorang auditor sehingga akan berdampak pada kinerjanya, Di lingkungan KAP auditorterkadang melakukan lembur dikarenakan harus menyelesaikan audit tepat waktu, auditor juga dituntut untuk mencapai hasil kerja yang maksimal, karena jika hasil kerja auditor maksimal, maka auditor dapat memberikan opini dengan tepat sehingga akan berpengaruh pada reputasi KAP itu sendiri. Lingkungan yang menyenangkan dapat memberikan kepuasan dalam bekerja serta rasa aman yang dapat memengaruhi peningkatan kinerja auditor.

Hasil penelitian Darmayanti (2018) menyatakan bahwa lingkungan kerja berpengaruh positif terhadap kinerja auditor. Iskandar (2017) menyatakan bahwa lingkungan kerja berpengaruh positif dan signifikan terhadap kinerja auditor. Berdasarkan uraian diatas, maka peneliti dengan ini mengajukan hipotesis sebagai berikut:

$\mathrm{H}_{4}$ : Lingkungan kerja berpengaruh positif pada kinerja auditor.

\section{METODE PENELITIAN}

Lokasi penelitian ini adalah Kantor Akuntan Publik yang bertempat di Bali yang diperoleh melalui Directory Institut Akuntan Publik Indonesia (IAPI) tahun 2019.Pemilihan lokasi pada Kantor Akuntan Publik yang bertempat di Bali yaitu untuk memudahkan pengumpulan data. Populasi dalam penelitian ini adalah seluruh auditor yang bekerja pada Kantor Akuntan Publik (KAP) di Bali. Pada penelitian ini populasi berjumlah 90 auditor. Metode penentuan sampel menggunakan non probability sampling dengan teknik sampling jenuh. Teknik sampling jenuh merupakan keseluruhan populasi yang dipilih menjadi sampel dengan jumlah 90 auditor. Analisis regresi liniear berganda digunakan untuk mengetahui ketergantungan satu variabel terikat pada satu variabel bebas atau tanpa variabel moderator, serta untuk mengetahui ketergantungan satu variabel terikat pada variabel-variabel bebas.Model persamaan regresi yang digunakan dalam penelitian ini diasumsikan linear dan diuji dengan tingkat signifikansi $\alpha=$ 0,05. Model regresi linear berganda yang digunakan adalah dengan menggunakan rumus:

$$
Y=\alpha+\beta_{1} X_{1}+\beta_{2} X_{2}+\beta_{3} X_{3}+\beta_{4} X_{4}+\varepsilon
$$

Keterangan :

$$
\begin{aligned}
& Y=\text { Kinerja Auditor } \\
& \mathrm{a}=\text { konstan }
\end{aligned}
$$




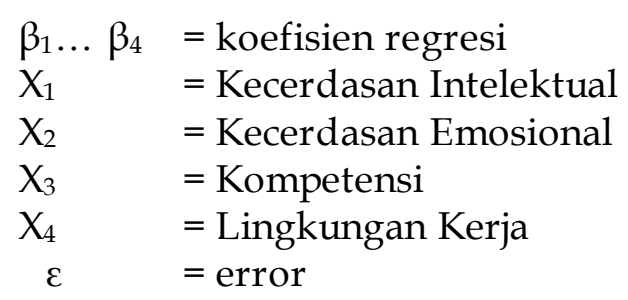

\section{HASIL DAN PEMBAHASAN}

Analisis statistik deskriptif adalah adalah gambaran atau deskripsi data yang dilihat dari nilai maksimum, nilai minimum, nilai rata-rata (mean) dan standar deviasi. Hasil analisis statistik deskriptif pada penelitian ini dapat dilihat pada Tabel 1.

Tabel 1. Hasil Analisis Statistik Deskriptif

\begin{tabular}{llllll}
\hline Variabel & $\mathrm{N}$ & Min. & Max. & Mean & Std. Deviasi \\
\hline Kecerdasan Intelektual $\left(\mathrm{X}_{1}\right)$ & 55 & 14.00 & 20.00 & 17.672 & 2.177 \\
Kecerdasan Emosional $\left(\mathrm{X}_{2}\right)$ & 55 & 15.00 & 20.00 & 16.945 & 1.947 \\
Kompetensi $\left(\mathrm{X}_{3}\right)$ & 55 & 18.00 & 24.00 & 20.490 & 2.167 \\
Lingkungan Kerja $\left(\mathrm{X}_{4}\right)$ & 55 & 14.00 & 20.00 & 16.945 & 1.909 \\
Kinerja Auditor $(\mathrm{Y})$ & 55 & 15.00 & 20.00 & 16.618 & 1.800 \\
\hline
\end{tabular}

Sumber: Data Penelitian, 2019

Nilai minimum variabel kecerdasan intelektualsebesar 14,00 nilai maksimum sebesar 20,00. Variabel kecerdasan intelektual diukur dengan 5 item pertanyaan yang terdiri dari 3 indikator yaitu kemampuan bahasa (verbal), kemampuan logika, dan kemampuan numerik dengan bantuan skala likert 4 poin. Variabel kecerdasan intelektual memiliki nilai rata-rata sebesar 17,672. Nilai rata-rata tersebut apabila dibagi dengan 5 item pertanyaan diperoleh hasil sebesar 3,525. Kriteria pengukuran tersebut menunjukkan bahwa semakin tinggi nilai rata-rata yang diperoleh menunjukkan semakin baik tanggapan responden terhadap item maupun variabel tersebut. Nilai rata-rata variabel kecerdasan intelektual sebesar 3,525 berada pada kriteria sangat tinggi yaitu pada rentang nilai 3,26-4,00, maka dapat dikatakan bahwa auditor di $10 \mathrm{KAP}$ di Bali memiliki kecerdasan intelektual yang sangat tinggi. Nilai standar deviasi variabel kecerdasan intelektual sebesar 2,177. Hal ini berarti nilai standar deviasi lebih rendah dibandingkan dengan nilai rata-rata, yang artinya kemampuan bahasa (verbal), logika dan numberik yang dimiliki auditor di $10 \mathrm{KAP}$ di Bali sangat baik sehingga menghasilkan kinerja yang baik.

Nilai minimum pada variabel kecerdasan emosional sebesar 15,00 dan nilai maksimum sebesar 20,00. Variabel kecerdasan emosional diukur dengan 5 item pertanyaan yang terdiri dari 5 indikator yaitu pengenalan diri, pengendalian diri, motivasi, empati dan keterampilan sosial, dengan bantuan skala likert 4 poin. Variabel kecerdasan emosional memiliki nilai rata-rata sebesar 16,945. Nilai rata-rata tersebut apabila dibagi dengan 5 item pertanyaan diperoleh hasil sebesar 3,389 Kriteria pengukuran tersebut menunjukkan bahwa semakin tinggi nilai rata-rata yang diperoleh menunjukkan semakin baik tanggapan responden terhadap item maupun variabel tersebut. Nilai rata-rata variabel kecerdasan emosiona lsebesar 3,389 berada pada kriteria sangat tinggi yaitu pada rentang nilai 3,26-4,00, maka dapat dikatakan bahwa auditor di $10 \mathrm{KAP}$ di Bali memiliki 
kecerdasan emosional yang sangat tinggi. Nilai standar deviasi variabel kecerdasan emosional sebesar 1,947 Hal ini berarti nilai standar deviasi lebih rendah dibandingkan dengan nilai rata-rata, yang artinya kemampuan pengenalan diri, pengendalian diri, motivasi, empati dan keterampilan sosial yang dimiliki auditor di $10 \mathrm{KAP}$ di Bali sangat baik sehingga menghasilkan kinerja yang baik.

Nilai minimum pada variabel kompetensi sebesar 18,00 dan nilai maksimum sebesar 24,00. Variabel kompetensi diukur dengan 6 item pertanyaan yang terdiri dari 3 indikator yaitu pengetahuan, keahlian, perilaku, dengan bantuan skala likert 4 poin. Variabel kompetensi memiliki nilai rata-rata sebesar 20,490. Nilai rata-rata tersebut apabila dibagi dengan 6 item pertanyaan diperoleh hasil sebesar 3,415. Kriteria pengukuran tersebut menunjukkan bahwa semakin tinggi nilai rata-rata yang diperoleh menunjukkan semakin baik tanggapan responden terhadap item maupun variabel tersebut. Nilai rata-rata variabel kompetensi sebesar 3,415 berada pada kriteria sangat tinggi yaitu pada rentang nilai 3,26-4,00, maka dapat dikatakan bahwa auditor di 10 KAP di Bali memiliki kompetensi yang sangat tinggi. Nilai standar deviasi variabel kompetensi sebesar 2,167. Hal ini berarti nilai standar deviasi lebih rendah dibandingkan dengan nilai rata-rata, yang artinya pengetahuan, keahlian dan perilaku yang dimiliki auditor di $10 \mathrm{KAP}$ di Bali sangat baik sehingga menghasilkan kinerja yang baik.

Nilai minimum pada variabel lingkungan kerja sebesar 14,00 dan nilai maksimum sebesar 20,00. Variabel lingkungan kerja diukur dengan 5 item pertanyaan yang terdiri dari 3 indikator yaitu suasana kerja, hubungan dengan rekan kerja, hubungan dengan klien,dengan bantuan skala likert 4 poin. Variabel lingkungan kerja memiliki nilai rata-rata sebesar 16,945. Nilai rata-rata tersebut apabila dibagi dengan 5 item pertanyaan diperoleh hasil sebesar 3,389. Kriteria pengukuran tersebut menunjukkan bahwa semakin tinggi nilai rata-rata yang diperoleh menunjukkan semakin baik tanggapan responden terhadap item maupun variabel tersebut. Nilai rata-rata variabel lingkungan kerja sebesar 3,389 berada pada kriteria sangat tinggi yaitu pada rentang nilai 3,26-4,00, maka dapat dikatakan bahwa auditor di 10 KAP di Bali memiliki lingkungan kerja yang sangat baik. Nilai standar deviasi variabel lingkungan kerja sebesar 1,909. Hal ini berarti nilai standar deviasi lebih rendah dibandingkan dengan nilai rata-rata, yang artinya suasana kerja, hubungan dengan rekan kerja dan hubungan dengan klien yang dimiliki auditor di $10 \mathrm{KAP}$ di Bali sangat baik sehingga menghasilkan kinerja yang baik.

Nilai minimum pada variabel kinerja auditor sebesar 15,00 dan nilai maksimum sebesar 20,00. Variabel kinerja auditor diukur dengan 5 item pertanyaan yang terdiri dari 3 indikator yaitu kualitas pekerja, kuantitas pekerjaan, ketepatan waktu, dengan bantuan skala likert 4 poin. Variabel kinerja auditor memiliki nilai rata-rata sebesar 16,618 Nilai rata-rata tersebut apabila dibagi dengan 5 item pertanyaan diperoleh hasil sebesar 3,323. Kriteria pengukuran tersebut menunjukkan bahwa semakin tinggi nilai rata-rata yang diperoleh menunjukkan semakin baik tanggapan responden terhadap item maupun variabel tersebut. Nilai rata-rata variabel kinerja auditor sebesar 3,323 berada pada kriteria sangat tinggi yaitu pada rentang nilai 3,26-4,00, maka dapat 
dikatakan bahwa auditor di 10 KAP di Bali memiliki kinerja auditor yang sangat baik. Nilai standar deviasi variabel kinerja auditor sebesar 1,800. Hal ini berarti nilai standar deviasi lebih rendah dibandingkan dengan nilai rata-rata, yang artinya kualitas pekerja, kuantitas pekerjaan dan ketepatan waktu dalam menyelesaikan tugas audit yang dimiliki auditor di $10 \mathrm{KAP}$ di Bali sudah sangat baik sehingga menghasilkan kinerja yang baik.

Tabel 2. Hasil Analisis Regresi Linier Berganda

\begin{tabular}{llllll}
\hline Model & \multicolumn{2}{l}{$\begin{array}{l}\text { Unstandardized } \\
\text { Coefficients }\end{array}$} & \multicolumn{2}{l}{$\begin{array}{l}\text { Standardized } \\
\text { Coefficients }\end{array}$} & \\
\cline { 2 - 5 } & B & Std.Error & Beta & T & Sig. \\
\hline (Constant) & -4.753 & 3.269 & & -1.454 & .152 \\
Kecerdasan intelektual & .200 & .095 & .242 & 2.099 & .041 \\
Kecerdasan emosional & .432 & .137 & .468 & 3.163 & .003 \\
Kompetensi & .252 & .095 & .304 & 2.642 & .011 \\
Lingkungan kerja & .315 & .098 & .334 & 3.220 & .002 \\
Dependen Variabel & Kinerja & & & & \\
R Square & 0,689 & & & & \\
Adjusted R Square & 0,664 & & & & \\
F Statistik & 27,721 & & & & \\
Signifikansi Uji F & 0,000 & & & &
\end{tabular}

Berdasarkan hasil analisis regresi linier berganda seperti yang disajikan pada Tabel 2, maka dapat dibuat persamaan regresi sebagai berikut:

$$
Y=-4,753+0,200 X_{1}+0,432 X_{2}+0,252 X_{3}+0,315 X_{4}+\varepsilon
$$

Berdasarkan hasil analisis pengaruh kecerdasan intelektual terhadap kinerja auditor diperoleh nilai signifikasi sebesar 0,041 dengan nilai koefisien regresi positif sebesar 0,200. Nilai Signifikansi 0,041 $\leq 0,050$ mengindikasikan bahwa $\mathrm{H}_{1}$ diterima. Hasil ini mempunyai arti bahwa kecerdasan intelektual berpengaruh positif dan signifikan terhadap kinerja auditor. Hasil penelitian menunjukan adanya hubungan antara kecerdasan intelektual dengan kinerja auditor, semakin tinggi kecerdasan intelektual yang dimiliki oleh seorang auditor maka kinerja auditor akan semakin meningkat. Sebaliknya, semakin rendah kecerdasan intelektual yang dimiliki seorang auditor maka kinerja auditor akan semakin menurun. Hasil ini juga sesuai dengan penelitian dari Yuliana \& Latrini (2016), serta Ratnantari \& Putri (2017).

Berdasarkan hasil analisis pengaruh kecerdasan emosional terhadap kinerja auditor diperoleh nilai signifikansi sebesar 0,003 dengan nilai koefisien regresi positif sebesar 0,432. Nilai Signifikansi 0,003 $\leq 0,05$ mengindikasikan bahwa $\mathrm{H}_{2}$ diterima. Hasil ini mempunyai arti bahwa Kecerdasan emosionalberpengaruh positif dan signifikan terhadap Kinerja auditor. Hal tersebut menunjukan bahwa variabel kecerdasan emosional berpengaruh positif pada kinerja auditor, dengan demikian hipotesis kedua $\left(\mathrm{H}_{2}\right)$ diterima. Hasil penelitian menunjukan adanya hubungan antara kecerdasan emosional dengan kinerja auditor, semakin tinggi kecerdasan emosional yang dimiliki oleh seorang auditor maka kinerja auditor akan semakin meningkat. Sebaliknya, semakin rendah kecerdasan intelektual yang dimiliki seorang auditor maka kinerja auditor akan semakin menurun. Hasil ini juga sesuai dengan penelitian dari Kristiyanti (2017), serta Apriyanti (2014). 
Berdasarkan hasil analisis pengaruh Kompetensi terhadap Kinerja auditor diperoleh nilai signifikansi sebesar 0,011 dengan nilai koefisien regresi positif sebesar 0,252. Nilai signifikansi $0,011 \leq 0,050$ mengindikasikan bahwa $\mathrm{H}_{3}$ diterima. Hasil ini mempunyai arti bahwa Kompetensi berpengaruh positif dan signifikan terhadap Kinerja auditor. Hasil penelitian menunjukan adanya hubungan antara kompetensi dengan kinerja auditor, semakin tinggi kompetensi yang dimiliki oleh seorang auditor maka kinerja auditor akan semakin meningkat. Sebaliknya, semakin rendah kompetensi yang dimiliki seorang auditor maka kinerja auditor akan semakin menurun. Hasil ini juga sesuai dengan penelitian dari Ariani \& Badera (2015), serta Yadnya \& Ariyanto (2017).

Berdasarkan hasil analisis pengaruh Lingkungan kerja terhadap Kinerja auditor diperoleh nilai signifikansi sebesar 0,002 dengan nilai koefisien regresi positif sebesar 0,315. Nilai signifikansi 0,002 $\leq 0,05$ mengindikasikan bahwa $\mathrm{H}_{4}$ diterima. Hasil ini mempunyai arti bahwa Lingkungan kerja berpengaruh positif dan signifikan terhadap Kinerja auditor. Hal tersebut menunjukan bahwa variabel lingkungan kerja berpengaruh positif pada kinerja auditor, dengan demikian hipotesis keempat $\left(\mathrm{H}_{4}\right)$ diterima. Hasil penelitian menunjukan adanya hubungan antara lingkungan kerja dengan kinerja auditor, semakin baik lingkungan kerja yang dimiliki oleh seorang auditor maka kinerja auditor akan semakin meningkat. Hasil ini juga sesuai dengan penelitian dari Darmayanti (2018) dan Iskandar (2017).

Koefisien determinasi berganda merupakan ukuran kesesuaian dari persamaan regresi, yaitu variasi dari variabel terikat yang mampu dijelaskan oleh variabel bebas. Kelemahan mendasar penggunaan koefisien determinasi adalah bias terhadap jumlah variabel yang dimasukan kedalam model. Setiap satu tambahan variabel independen, maka $\mathrm{R}^{2}$ pasti meningkat tidak peduli apakah variabel tersebut berpengaruh secara signifikan terhadap variabel dependen. oleh karena itu peneliti mengunakan nilai $A j u s t e d R^{2}$ pada saat mengevaluasi yang mana model regresi terbaik, karena tidak seperti $\mathrm{R}$ square, nilaiAjusted $\mathrm{R}$ square dapat naik atau turun apabila satu variabel independen ditambahkan ke dalam model (Ghozali, 2016:95). Adapun hasil uji koefisien determinasi dalam penelitian ini dapat dilihat pada Tabel 3, berikut.

Tabel 3. Hasil Uji Koefisien Determinasi

\begin{tabular}{lllll}
\hline Model & & & & Std. Error of the \\
& $\mathrm{R}$ & R Square & Adjusted $R$ Square & Estimate
\end{tabular}

Sumber: Data Penelitian, 2019

Besarnya pengaruh variabel bebas terhadap variabel terikat yang ditunjukkan oleh nilai determinasi total (AjustedR Square) sebesar 0,664 mempunyai arti bahwa sebesar 66,4\% variasi Kinerja auditor dipengaruhi oleh variasi Kecerdasan intelektual, Kecerdasan emosional, Kompetensi, dan Lingkungan kerja, sedangkan sisanya sebesar 33,6\% djelaskan oleh faktor lain yang tidak dimasukkan ke dalam model.

Uji kelayakan model regresi bertujuan untuk mengetahui apakah semua variabel bebas yang diidentifikasi (kecerdasan intelektual, kecerdasan emosional, kompetensi, lingkungan kerja) tepat digunakan memprediksi kinerja auditor . Uji ini sering juga disebut dengan uji $\mathrm{F}$. 
Tabel 4. Hasil Uji F

\begin{tabular}{llrrrrr}
\hline Model & & Sum of Squares & Df & Mean Square & \multicolumn{1}{c}{ S } & \multicolumn{1}{c}{ Sig. } \\
\hline 1 & Regression & 120.600 & 4 & 30.150 & 27.721 & $.000^{\mathrm{a}}$ \\
& Residual & 54.382 & 50 & 1.088 & & \\
& Total & 174.982 & 54 & & & \\
\hline
\end{tabular}

Sumber: Data Penelitian, 2019

Hasil pengolahan data pada Tabel 4, dengan menggunakan program

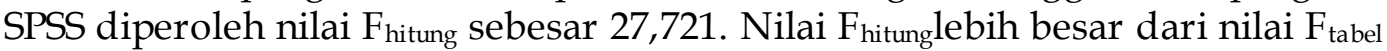
sebesar 2,55 dan nilai signifikansi F sebesar 0,000 nilai ini lebih kecil dari 0,05, sehingga dapat disimpulkan bahwa ada pengaruh signifikan antara faktor kecerdasan intelektual, kecerdasan emosional, kompetensi, dan lingkungan kerja secara simultan terhadap kinerja auditor.

\section{SIMPULAN}

Hasil penelitian ini sejalan dengan teori atribusi, dimana teori ini menjelaskan tentang penyebab terjadinya perilaku seseorang baik dari faktor internal maupun faktor eksternal. Terdapat bukti empiris yang diperoleh melalui penelitian ini yang menunjukkan bahwa kecerdasan intelektual, kecerdasan emosional, kompetensi dan lingkungan kerja berpengaruh positif pada kinerja auditor, dalam penelitian ini faktor internal yang mempengaruhi kinerja auditor adalah kecerdasan intelektual, kecerdasan emosional dan kompetensi, sedangkan faktor eksternalnya berupa lingkungan kerja.

Hasil penelitian ini dapat memberikan gambaran dan masukan bagi pimpinan Kantor Akuntan Publik dalam mengupayakan kinerja yang lebih baik, serta bagi auditor dapat digunakan sebagai bahan evaluasi untuk menjaga dan meningkatkan kinerjanya dalam melakukan audit. Hasil penelitian ini juga dapat menjadi pertimbangan bagi klien dalam memilih auditor yang profesional dan berpengalaman.

\section{REFERENSI}

Amilin, A. (2017). The Impact of Role Conflict and Role Ambiguity on Accountants' Performance: The Moderating Effect of Emotional Quotient. European Research Studies Journal, 20(2), 237-249.

Apriyanti, Taufik, T., \& Mudrika, A. H. (2014). Pengaruh Kecerdasan Emosional, Kecerdasan Spiritual Dan Perilaku Etis Terhadap Kinerja Auditor Pemerintah (Studi Empiris pada BPK-RI dan BPKP Perwakilan Provinsi Riau). Jurnal Akuntansii, Fakultas Ekonomi Universitas Riau, Pekanbaru, 1(2), 115. https://doi.org/10.1016/j.cell.2009.01.043

Ariani, K., \& Badera, I. (2015). Pengaruh Integritas, Obyektivitas, Kerahasiaan, Dan Kompetensi Pada Kinerja Auditor Inspektorat Kota Denpasar. E-Jurnal Akuntansi Universitas Udayana, 10(1), 182-198.

Brown, P. A., Stocks, M. H., \& Wilder, W. M. (2007). Ethical exemplification and the AICPA code of professional conduct: An empirical investigation of auditor and public perceptions. Journal of Business Ethics, 71(1), 39-71. https://doi.org/10.1007/s10551-006-9124-3

Ciarrochi, J., Deane, F. P., \& Anderson, S. (2002). Emotional Intelligence Moderates the Relationship between Stress and Mental Health. Personality 
and Individual Differences, 32(2), 197-209. https://doi.org/10.1016/s00104655(98)00074-5

Cook, G. L., Bay, D., Visser, B., Myburgh, J. E., \& Njoroge, J. (2011). Emotional Intelligence: The Role of Accounting Education and Work Experience. Issues in Accounting Education, 26(2), 267-286. https://doi.org/10.2308/iace-10001

Darmayanti, N. (2018). Pengaruh Stress Kerja, Faktor Lingkungan, Dan Budaya Organisasi Terhadap Kinerja Auditor Independen (Studi Pada Auditor Independen Kantor Akuntan Publik Di Surabaya). J-MACC: Journal of Management and Accounting, 1(1), 55-69.

Dharmanegara, I., Sitiari, N., \& Wirayudha, I. (2016). Job Competency and Work Environment : the effect on Job Satisfaction and Job Performance among SMEs Worker. IOSR Journal of Business and Management (IOSR-JBM), 18(1), 19-26. https://doi.org/10.9790/487X-18121926

Erawan, N. M. A. N. P. (2018). Pengaruh Kompetensi , Pengalaman Kerja , Gaya Kepemimpinan dan Lingkungan Kerja Pada Kualitas Audit. E-Jurnal Akuntansi Universitas Udayana, 24(3), 2360-2388.

Furiady, O., \& Kurnia, R. (2015). The Effect of Work Experiences, Competency, Motivation, Accountability and Objectivity Towards Audit Quality. Procedia - Social and Behavioral Sciences, 211, 328-335. https://doi.org/10.1016/j.sbspro.2015.11.042

Ghozali, I. (2016). Aplikasi Analisis Multivariative Dengan Program IBM SPSS 23 (Edisi 8). Semarang: Badan Penerbit Uniersitas Diponogoro.

Hasanuddin, R., \& Sjahruddin, H. (2017). The Structure of Emotional Intelligence, Spiritual Intelligence and Its Relationship with Work Enthusiasm and Auditor Performance. World Journal of Business and Management, 3(1), 67-85. https://doi.org/10.5296/wjbm.v3i1.11321

Husam, A., Rana, A. N., \& Abdulhadi, R. (2013). Factors Affecting The Quality of Auditing: The Case of Jordanian Commercial Banks Accounting Department, College of Business. International Journal of Business and Social Science, 4(11), 206-222.

Iskandar. (2017). Pengaruh Karakteristik Individu, Beban Kerja Dan Lingkungan Kerja Terhadap Kinerja Pegawai Pada Kantor Inspektorat Daerah Provinsi Sulawesi Tengah. Katalogis, 5(1), 68-79.

Kalbers, L. P., \& Fogarthy, T. J. (1995). Professionalism and Its Concequences: A Study of Internal Auditors. Auditing: A Journal of Practice and Theory, 14(1), 64-86.

Kristiyanti, L. (2017). Pengaruh Emotional Quotient Dan Self Efficacy Terhadap Kinerja Auditor (Studi Kasus Kantor Akuntan di Surakarta dan Yogyakarta). Jurnal Akuntansi Dan Pajak, 16(01), 88-102. https://doi.org/10.29040/jap.v16i01.24

Pitaloka, E., \& Sofia, I. P. (2014). The Affect of Work Environment, Job Satisfaction, Organization Commitment on OCB of Internal Auditors. International Journal of Business, Economics and Law, 5(2), 10-18. https://doi.org/10.1097/01.JNR.0000387319.28010.5e

Ratnantari, I. G. A. M., \& Putri, I. G. A. M. A. D. (2017). Pengaruh Kecerdasan Intellektual, Kecerdasan Emosional, Kecerdasan Spiritual, Indepedensi dan Komitmen Organisasi pada Kinerja Auditor. E-Jurnal Akuntansi Universitas 
Udayana, 20(1), 814-844.

Robbins, S. P., \& Judge, T. A. (2008). Perilaku Organisasi (Ke-12). Jakarta: Salemba Empat.

Sony, M., \& Mekoth, N. (2016). The Relationship Between Emotional Intelligence, Frontline Employee Adaptability, Job Satisfaction and Job Performance. Journal of Retailing and Consumer Services, 30, 20-32. https://doi.org/10.1016/j.jretconser.2015.12.003

Tubbs, R. M. (1992). The Effect of Experience on the Auditor's Organization and Amount of Knowledge. The Accounting Review, 67(4), 783-801.

Wardhani, R. S., \& Lesmana, I. (2014). Analisis Faktor-Faktor yang Mempengaruhi Pemilihan Karir Akuntan Bagi Mahasiswa Akuntansi (Studi Pada Jurusan Akuntansi FE Universitas Bangka Belitung). Jurnal Akuntansi (Media Riset Akuntansi \& Keuangan), 2(1), 48-62.

Watkin, C. (2000). Developing Emotional Intelligence. International Journal of Selection and Assesment, 8(2), 89-92.

Wiguna, I. P. I., \& Yadnyana, K. (2019). The role of working experience moderating the effect of emotional intelligence, intellectual intelligence, and spiritual intelligence on the ethical decision of tax consultants in Bali area. International Research Joumal of Management, IT and Social Sciences, 6(3), 18-28. https://doi.org/10.21744/irjmis.v6n3.624

Wu, T. H., Huang, S. M., Huang, S. Y., \& Yen, D. C. (2017). The Effect of Competencies, Team Problem-Solving Ability, and Computer Audit Activity on Internal Audit Performance. Information Systems Frontiers, 19(5), 1133-1148.

Yadnya, I. P. P., \& Ariyanto, D. (2017). Pengaruh Kompetensi Dan Independensi Pada Kinerja Auditor Dengan Etika Auditor Sebagai Variabel Moderasi. EJurnal Akuntansi Universitas Udayana, 19(2), 973-999.

Yuliana, G., \& Latrini, M. (2016). Pengaruh Kecerdasan Emosional, Kecerdasan Spiritual, Kecerdasan Intelektual Dan Independensi Pada Kinerja Auditor. E-Jurnal Akuntansi Universitas Udayana, 16(2), 1034-1062. 